\title{
Disappearance of FDG uptake on PET scan after antimicrobial therapy could help for the diagnosis of Coxiella burnetii spondylodiscitis
}

\author{
Marine Gaudé, ${ }^{1}$ Saison Julien, ${ }^{1,2}$ Frédéric Laurent, ${ }^{2,3,4}$ Tristan Ferry, $^{1,2,4}$ on behalf of \\ the Lyon BJI Study Group
}

\begin{abstract}
${ }^{1}$ Service de Maladies Infectieuses et Tropicales, Hôpital de la Croix-Rousse, Hospices Civils de Lyon, Lyon, France

${ }^{2}$ Université Claude Bernard Lyon 1, Lyon, France

${ }^{3}$ Laboratoire de Bactériologie, Hôpital de la Croix-Rousse, Hospices Civils de Lyon, Lyon, France

${ }^{4}$ Centre International de Recherche en Infectiologie (CIRI), Inserm U1111, CNRS UMR5308, ENS de Lyon, UCBL1, Lyon, France
\end{abstract}

Correspondence to Dr Tristan Ferry, tristan.ferry@univ-lyon1.fr

Accepted 11 March 2016

\section{DESCRIPTION}

A 55 year-old man was admitted for worsening of a chronic low back pain associated with L4-L5 anterolisthesis, despite taking non-steroidal antiinflammatory drugs for several months. He had a medical history of high blood pressure and obesity (body mass index, $37 \mathrm{~kg} / \mathrm{m}^{2}$ ). He lived in the countryside but had no direct contact with animals except his dog. There were no fever, chills, sweats or weight loss. C reactive protein (CRP) was $<2.9 \mathrm{mg} / \mathrm{L}$. Radiographs showed L4-L5 anterolisthesis with endplate erosions and bony sclerosis (figure 1A). On MRI (figure 1B), there was a significant enhancement of L4-L5 vertebral endplates and paravertebral soft tissues. Positron emission tomography (PET) CT scan showed an intense uptake of the L4-L5 space (figure 1C). Blood and CT-guided discovertebral cultures remained sterile (including for mycobacteria) and 16s PCR and in-house specific Coxiella burnetii PCR were negative. C. burnetii serology (Focus diagnostics Q fever immunofluorescent antibody $\operatorname{IgG}$ and $\operatorname{IgM}$ test kits) was positive and in favour of a chronic Q fever (phase I, IgG 2048; phase II, IgG 4096; IgM were negative). Brucella and Bartonella were negative. An echocardiogram was performed to exclude vegetations caused by bacterial endocarditis. The patient was treated with doxycycline $(200 \mathrm{mg} /$ day $)$ and hydroxychloroquine $(400 \mathrm{mg} /$ day $)$ for 10 months. A significant improvement with reduction of the back pain was noticed and the CRP remained $<2.9 \mathrm{mg} / \mathrm{L}$. The antibody titres decreased and the pathological uptake of the L4-L5 space on PET scan disappeared when antibiotics were stopped (figure 1D).

Q fever is a worldwide zoonotic acute or chronic infection. ${ }^{1}$ Osteoarticular localisations are infrequent, insidious and remain difficult to diagnose. ${ }^{2} 3$ PCRs performed on bone biopsy could be negative. Disappearance of a significant spine uptake on PET CT scan and decreasing of antibody titres could help for treatment discontinuation during C. burnetii spondylodiscitis.
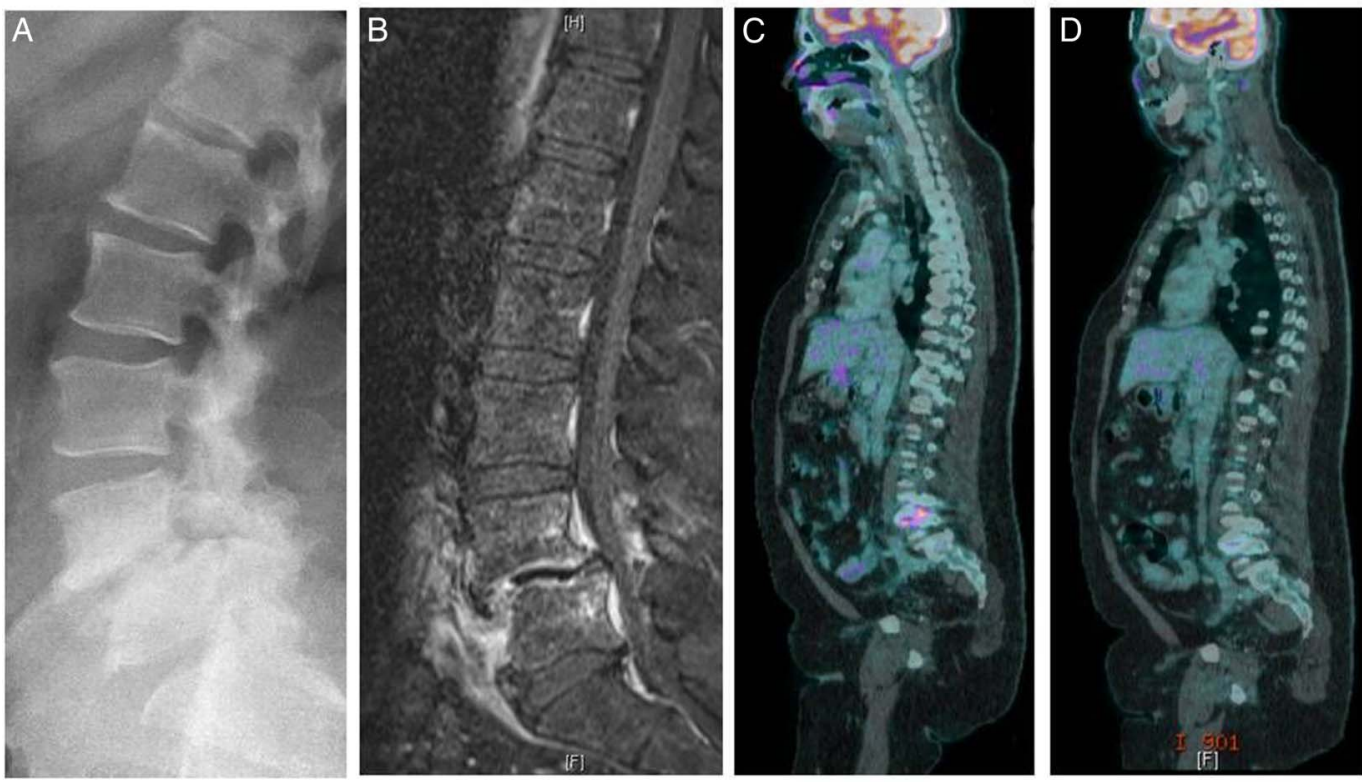

Figure 1 (A) Lateral lumbar radiograph revealing a L4-L5 anterolisthesis; (B) MRI of the lumbar spine, T1-weighted gadolinium sequence, showing a gadolinium enhancement of the L4-L5 vertebral endplates; (C) Positron emission tomography (PET) scan image fusion showing an intense uptake of the L4-L5 space with a maximum standardised uptake value of 7.4; (D) PET scan image fusion showing a significant reduction of the fluorescent deoxyglucose uptake of the L4-L5 space after 10 months of treatment. 


\section{Learning points}

- Coxiella burnetii has to be suspected in patients with spondylodiscitis with sterile standard cultures from bone biopsy.

- C. burnetii-specific PCR and 16s PCR performed on bone biopsy could be negative in patients with $C$. burnetii spondylodiscitis and serology remains the cornerstone of diagnosis.

- Disappearance of a significant spine uptake on positron emission tomography CT scan and decreasing of antibody titres could help for treatment discontinuation during $C$. burnetii spondylodiscitis.

Collaborators Lyon Bone and Joint Infection Study Group: Physicians-Tristan Ferry, Thomas Perpoint, André Boibieux, François Biron, Florence Ader, Julien Saison, Florent Valour, Sandrine Roux, Fatiha Daoud, Johanna Lippman, Evelyne Braun, Marie-Paule Vallat, Patrick Miailhes, Christian Chidiac, Yves Gillet, Laure Hees; Surgeons-Sébastien Lustig, Philippe Neyret, Olivier Reynaud, Adrien Peltier,
Anthony Viste, Jean-Baptiste Bérard, Frédéric Dalat, Olivier Cantin, Romain Desmarchelier, Thibault Vermersch, Michel-Henry Fessy, Cédric Barrey, Francesco Signorelli, Emmanuel Jouanneau, Timothée Jacquesson, Ali Mojallal, Fabien Boucher, Hristo Shipkov, Mehdi Ismail, Joseph Chateau; Microbiologists —Frederic Laurent, François Vandenesch, Jean-Philippe Rasigade, Céline Dupieux, Sophie Trouillet-Assant; Nuclear Medicine-Isabelle Morelec, Marc Janier, Francesco Giammarile; PK/PD specialists—Michel Tod, Marie-Claude Gagnieu, Sylvain Goutelle; Clinical Research Assistant-Eugénie Mabrut.

Contributors All the authors contributed significantly to the writing of the case. TF, MG and SJ participated in the patient's care. FL performed the microbiological analyses.

Competing interests None declared.

Patient consent Obtained.

Provenance and peer review Not commissioned; externally peer reviewed.

\section{REFERENCES}

1 Raoult D, Marrie T, Mege J. Natural history and pathophysiology of Q fever. Lancet Infect Dis 2005;5:219-26.

2 Landais C, Fenollar F, Constantin A, et al. Q fever osteoarticular infection: four new cases and a review of the literature. Eur I Clin Microbiol Infect Dis 2007;26:341-7.

3 Merhej V, Tattevin P, Revest M, et al. Q fever osteomyelitis: a case report and literature review. Comp Immunol Microbiol Infect Dis 2012;35:169-72.

Copyright 2016 BMJ Publishing Group. All rights reserved. For permission to reuse any of this content visit

http://group.bmj.com/group/rights-licensing/permissions.

BMJ Case Report Fellows may re-use this article for personal use and teaching without any further permission.

Become a Fellow of BMJ Case Reports today and you can:

- Submit as many cases as you like

- Enjoy fast sympathetic peer review and rapid publication of accepted articles

- Access all the published articles

- Re-use any of the published material for personal use and teaching without further permission

For information on Institutional Fellowships contact consortiasales@bmjgroup.com

Visit casereports.bmj.com for more articles like this and to become a Fellow 